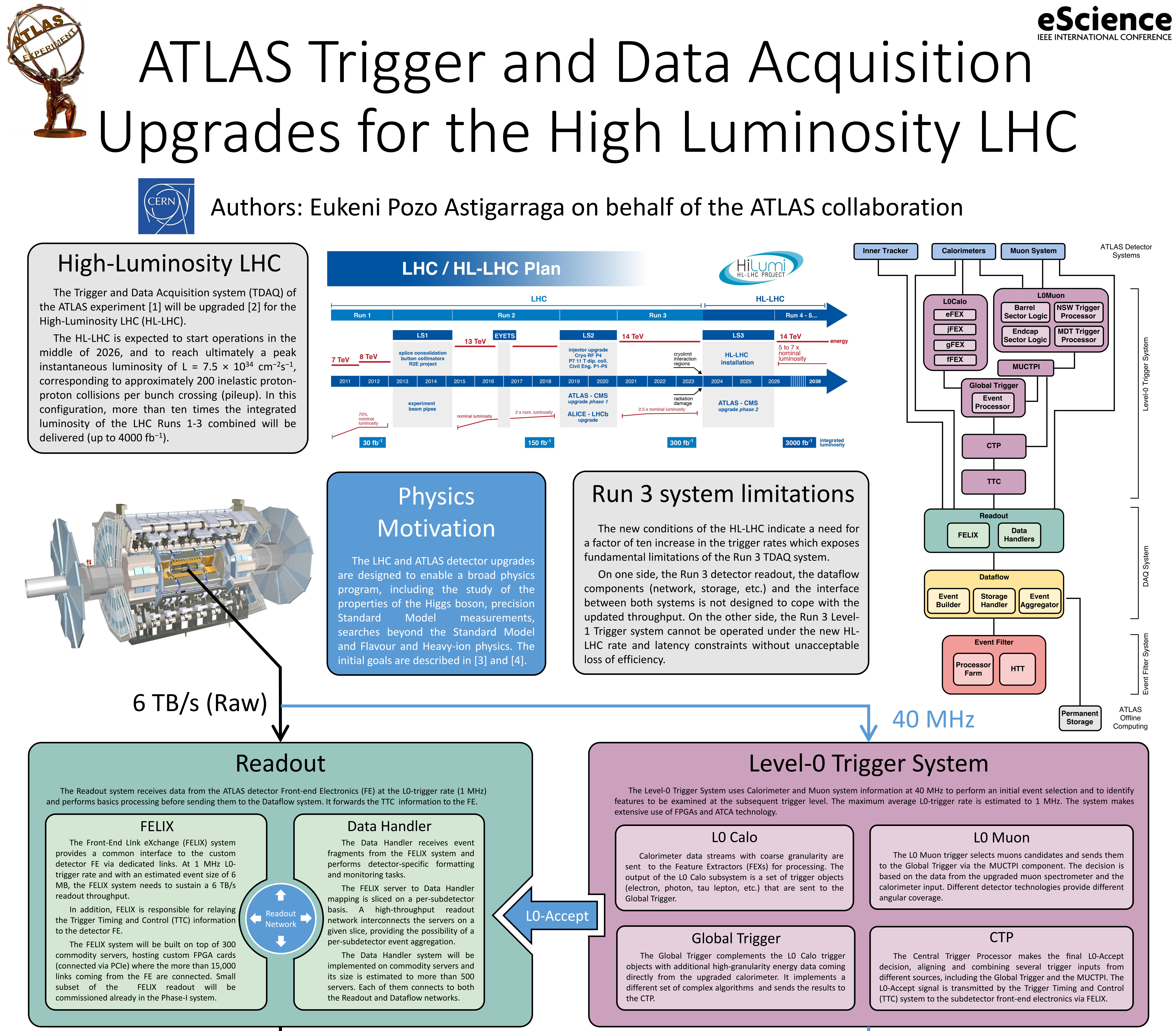

\title{
$6 \mathrm{~TB} / \mathrm{s}$ (Processed) $\downarrow$
}

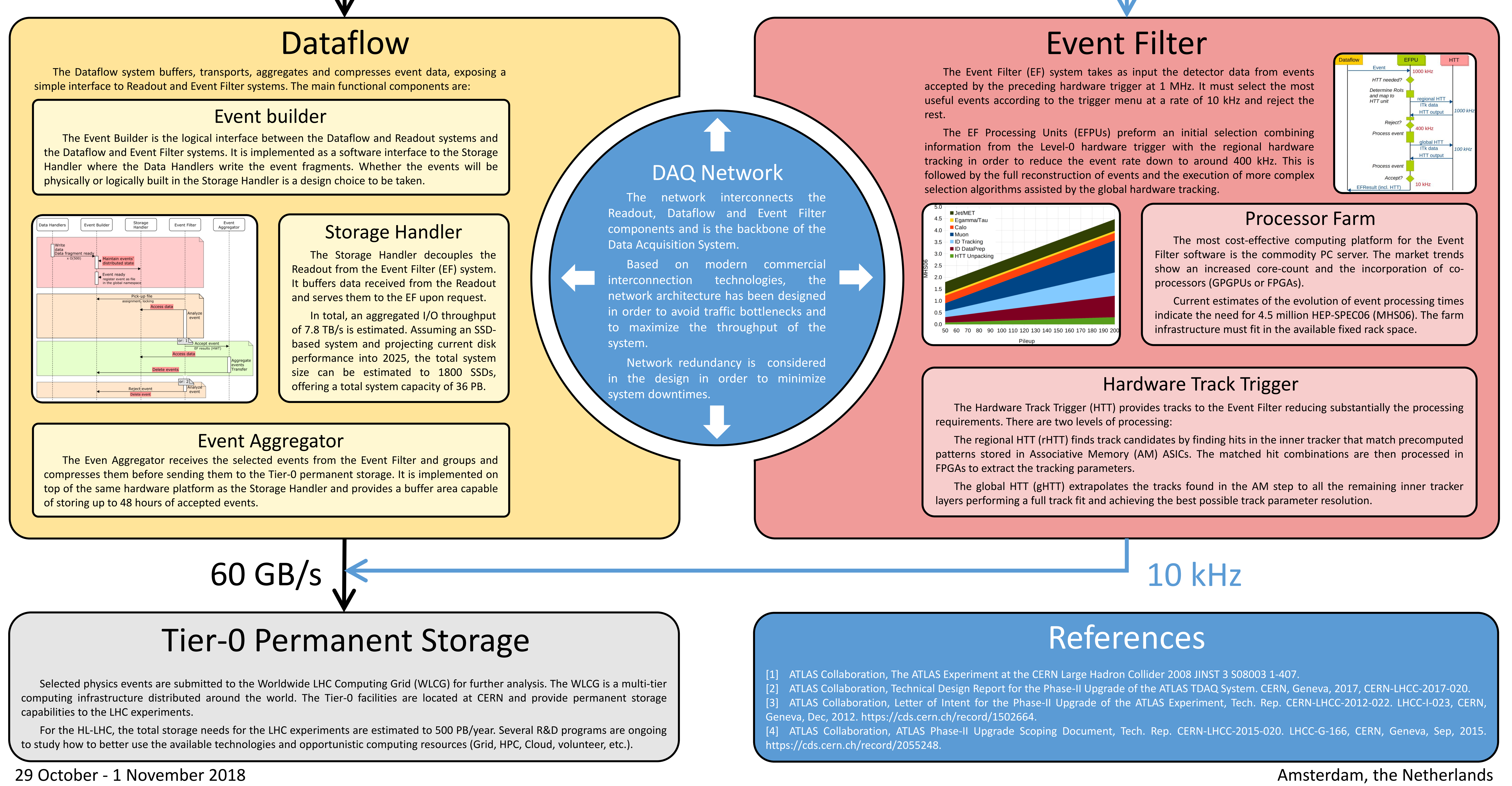

